\title{
Comparative Histomorphologic Studies of the Heart in Three Mammalian Species: Rabbits (Oryctolagus guniculus), Wistar Rats (Rattus norvegicus) and African Giant Rats (Cricetomys gambianus)
}

\section{Ibegbu, Augustine O; Yahaya, Buhari Olalekan; Adubazi Paul; and Musa, Sunday A. \\ Department of Human Anatomy, Faculty of Medicine, Ahmadu Bello University Zaria- Kaduna State-Nigeria 81006}

With 6 figures and 5 tables

\section{Abstract}

Comparative morphologic, morphometric and histological studies was carried out on adult male hearts of the three mamalian species namely the Rabbit (Oryctolagus cuniculus), Wistar rats (Rattus norvegicus) and African giant rats (Cricetomys gambianus). Five animals from each species were weighed, lightly anasthetized with chloroform and humanely sarcrificed. The thoracic cage was carefully opened and the hearts were removed, morphologically observed andfixed in Bouins fluid. The tissues were processed for histological studies and stained using Haematoxylin and eosin $(\mathrm{H}$ \& E) and Rafferty's stain. The hearts were physically observed to be reddish in colour and pear shaped. The heart of the three mamalian

J. Vet. Anat. species showed the aorta, superior and inferior vena cava and the pulmunary vessels similar to that of the humans. The mean total body weight of the African gaint rats, Rabbits and Wistar rats are $1.167 \pm 0.153 \mathrm{~kg}, 1.233 \pm 0.252 \mathrm{~kg}$ and $20.333 \pm 5.774 \mathrm{~g}$ respectively, which showed a significant difference ( $P \leq 0.01)$ between the body weight of the African gaint rats, Rabbits and the Wistar rats. The mean weight of the hearts of African giant rats, Rabbits and Wistar rats are 4.367 \pm 1.620 , $3.306 \pm 0.115,0.766 \pm 0.164$

gms respectively which showed a significant difference $(P \leq 0.01)$ between the hearts of African gaint rats, Rabbits and Wistar rat. Histologically, the atrial and ventricular parts of the heart of the three species showed great similarities in 
terms of the arrangement of the cardiac muscle cells and the layersof the walls of the heart in the three mamalian species with little differences observed in the morphometrics of the muscle fibres and intra-muscular cellular distribu-tions in the different hearts studied which could be due to the sizes of the mammals in general.

Key Words: Comparative, Morphology, Heart, Wistar rat, African giant rat, Rabbit

\section{Introduction}

Comparative anatomy is the study of similarities and differences in the anatomy of different organisms and it is closely related to evolutionary biology and phylogeny. Histomorphometry on the other hand is the quantitative study of the microscopic organization and structures of a tissue, an organ or a system by a microscope (Campbell and Reece, 2002; Caldwell, 2006). Comparative histomorphometrics study the simila-rities and differences in microscopic organiza-tions and structures of the heart of the three species from the whole organ down to the tissue level by analysis of their measurements (Eroschenko, 2003; Perry, 2006).

Rabbits are small mammals found in several parts of the world, the male is the buck and the female is the doe. Rabbits have long ears which can be more than $10 \mathrm{~cm}$ long which are probably an adaptation for detecting predators(Wilson and Burnie, 2001; Wilson and Reeder, 2005). They have large powerful hindlegs, the two front pairs have five toes, the extra called dew claw (Romer et al., 1977; Sharon and Crowell, 2010). They are pentigrade animals while at rest, however they move around on their toes while running, assuming a more digitigrade form(Wilson and Burnie, 2001). The fur is most commonly long and soft, with colors such as shades of brown, gray, and buff, the tail is a little plume of brownish fur with white on top for cotton tails. Rabbits have very complex needs, being aware of how wild rabbits live can help you understand what rabbits need (Dyce et al., 1996, Sharon and Crowell, 2010). Rabbits are herbivores, that feed by grazing on grass, forbs, and leafy weeds.

The Gambian pouched rats (Cricetomys gambianus), known as the African giant rat, are nocturnal rats and are among the largest mucoids in the world, growing up about 0.9 meters (3ft) long including their tail which makes up half their length (Perry, 2006; Sharon and Crowell, 2010). It is wide-spread insub-saharan Africa and has a very poor eyesight and so depends on its senses of smell and hearing (Happold, 
1987; Kingdon, 1997). It is not a true rat but is part of a uniquely African branch of mucoid rodents. It typically weighs between 1 and 1.4 $\mathrm{kg}$ in its native Africa. The African giant rats have cheek pouches which allow it to gather up several kilograms of nuts per night for storage underground (Ajayi, 1975; Kingdon,1997; Perry, 2006). The burrow consists of a long passage with side alleys and several chambers. They are completely omnivorous, feeding on vegetables, insects, crabs, snails, and other items but apparently prefering palm fruits and palm kernels (Ajayi, 1975; Kingdon, 1997; Perry, 2006). These rats store a considerable amount of foods as well as non-edible items such as coins, metals, and bits of cloth.In a study of captives, Ajayi observed one female to give birth 5 times in 9 months, and he thought that probably females could produce 10 litters annually (Ajayi, 1975; van der Straeten, et. al., 2008). The gestation period was 27-36 days. Litters numbered 1-5 and Sexual maturity is attained at about 20 weeks of age (Perry, 2006).

Wistar rats or laboratory ratsare of the species Rattus norvegicus which is bred and kept for scientific research (Young, 1981; Kriegs et al., 2006). Wistar rats differ from wild rats in many ways, they are calmer and less likely to bite and

J. Vet. Anat. can tolerate greater crowding (Kemp, 1982; Witmer, et al., 2010). They breed earlier and produce more off-springs. Over the past years, two breeding lines derived originally from outbred Wistar rats have been established that differ markedly and consistently in their anxiety related behaviour in the elevated plus maze (Witmer, et al., 2010; Davoust et al., 2013). Wistar rats are commonly fed and watered ad-libitum. They are fed with a laboratory quality rodent chow (Young, 1981; Wilson and Reeder, 2005). The average diet contains about $18-24 \%$ protein, 4$7 \%$ fat, and $60-75 \%$ carbon-hydrate respectively (van Zuphten, et al., 2001; Wilson and Reeder, 2005).

Rodents consume and damage human foods in the fields and in stores and they spoil the foods in stores by urine and droppings reducing their sale values (Baumans, et al., 2001; Perry, 2006). Their gnowing and burrowing habit, destroy many articles such as packaging, clothes, furnitures and structures like floors, buildings, and bridges, by gnowing through electrical cables they can cause fires (Betelak, et al., 2001; Cecie at al., 2009). Rodents can be responsible for transmitting diseases dangerous to man and are important animals used for research in psychology, medicine, and other 
fields (Cooper, 2008; Davoust et al., 2013). The aim of the present work was to study the comparative morphology and histomorphometrics of the hearts of three mammalian speices namely the Rabbits, (Oryc-tolagus cuniculus), Wistar rats (Rattus norvegicus) and African giant rats (Cricetomys gambianus).

\section{Material and Method}

A total number of 5 animals of each specieswere obtained from the Faculty of Veterinary Medicine Animal house, Ahmadu Bello University, Zaria and was housed in the Depart-ment of Human Anatomy Laboratory in animal cages. The animals were physically observed and vital signs were checked to see if the animals were apparently healthy. The animals were then weighed and allowed to acclimatize for two weeks and the weights were again taken before the comencement of the study. The animals were fed with animal feeds and Water was given ad libitum.

The animals were sacrificed humanely by anaesthesizing them with chloro-form inhalation and were perfused using formal salaine, the thoracic cage was opened and the hearts were removed. Physical observations were made to see the position and orientation of the hearts and the vessels.

\section{Morphologic Studies of the}

\section{Rodents's Hearts}

The structural and morphological characteristics of the hearts of each of the animals in each group were examined with the naked eyes. These include the shape, size, and the external landmarks of the atria and ventricles were evaluated in each of the hearts of the species.

\section{Morphometric Studies of the Rodents's Hearts}

The animals were anaesthesized using chloroform, and then weighed using a sensitive digital balance. They were sacrificed and their hearts were removed and immediately placed into the bouin's fluid fixative. The hearts were then weighed using a digital micro scale, followed by the measure-ment of heart volumes and the hearts were dissected and the chambers as well as the thickness of the walls and of the heart valves. The fixed hearts were processed routinely and stained using H\&E staining method, as well as Rafferty's stain (Weiss et al., 2010).

\section{Statistical Analysis}

Data obtained were expressed as means \pm standard deviation (SD). Differences between group means were estimated using Students' Ttest and one-way analysis of variance (ANOVA) followed by Posthock Turkey's test using SPSS 12.0 for windows. A P value less than or 
equal to 0.05 was considered to be significant (Sellke et al., 2001).

\section{Result}

\section{Physical Observations}

Physical and Gross observations showed that the heart of the three species have red coloration due to presence of blood vessels and reddish coloration of the heart muscles. The orientation of the heart were seen to be lying in the midline plane and was tilted to the left side partially thereby making the right lungs having a larger surface area than the left. The apex of the hearts of the three mammals were seen facing down-wards as seen in that of humans. The aorta was clearly seen as well as the cranial and caudal vena cava, the pulmonary vessels were also seen from mere viewing of the rodent's heart with the naked eyes.

\section{Mophological Observations}

The morphological observation seen in the three hearts revealed a significant differences in the measurements of the heart parameters namely; heart weight, heart volume, lenght and width of the four heart chambers as well as thickness of heart walls and valves. Based on the morphology, the African giant rats have the biggest heart and have the largest sizes of the J. Vet. Anat. chambers of the heart excluding the left ventricle where the Rabbits have the largest size as shown in Table 1. The result showed that the African giant rats have the largest heart chambers apart from the right atrium in which the rabbit predominates, this is due to the origin of the longitudinal sulcus dividing the heart of the African giant rats that deviates to the right at the arterial part of the heart making the right atrium remarkably smaller than the left one.

\section{Mophometric Observations}

The result of the morphometric study showed the African giant rat posse-ssed the highest values in most of the parameters taken, apart from the right atrium in which the rabbit had the highest value in terms of width and thickness of the walls of the right atrium and right ventricle as well as the intra-ventricular septum as shown in Table 2. for the width of the various heart chambers in which the African giant rats have the highest values for the width of the right and left atria and have the highest value of the right and left ventricles which showed a significant difference $(P \leq 0.01)$, between the African gaint rats and Wistar ratsand between the Rabbits and Wistar rats. In the right ventricles, left atria and left ventricles of the three mammals, there was a 
significant difference $(P \leq 0.01)$ between the African gaint rats and Wistar rats and between the Rabbits and Wistar rats.

The result of the thickness of the heart walls of the three species showed that the Rabbits had thickest wall of the right atrium and ventricles whereas a smaller value in terms of thickness on the left side while the African giant rats showed the highest values in the left compartment. The Rabbitsalso had the thickest intra-ventricular septa compared to the two. In both the right and left atrio-ventricular septa, the African giant rats predominates as shown in Table (3).

The results presented inTable 4 show the correlation between the total body weight in relation to the heart weight and heart volumes in the three species. The rabbit showed a significant correlation between the total body weight and the heart weight and heart volume and also between the heart weight and heart volume. In the African giant rats the correlation observed was in the total body weight and heart volume as well as between the heart weight and heart volume. In the wistar rat the only correlation observed was in the total body weight and heart weight.

\section{Histo-Morhpometrics}

This is the measurement of the lenght and width of a single ventricular cardiac muscle fibre in the heart of the three rodents as well as the intercellular space between two adjacent single muscle fibres, both of which were measured in micrometers. These measurements were taken under a magnification of $X 400$.The lenght of the ventricular cardiac muscle fibres showed great variations and as a result of these, five ven-tricular cardiac muscle fibres were randomly selected, measured and then analysed for cardiac muscle lenght in the three mammalian species. Wistar rat heart muscle fibres hada length ranging from $37.5 \mu \mathrm{m}$ to $72.5 \mu \mathrm{m}$ and width ranging from $30 \mu \mathrm{m}$ to $42.5 \mu \mathrm{m}$, with intercellular space of $15.5 \mu \mathrm{m}$ to $20 \mu \mathrm{m}$. Rabbit heart muscle fibres have a length ranging from $57.5 \mu \mathrm{m}$ to $100 \mu \mathrm{m}$ and width ranging from $32.5 \mu \mathrm{m}$ to $50 \mu \mathrm{m}$, with inter-cellular space which ranges from $17.5 \mu \mathrm{m}$ to $25 \mu \mathrm{m}$. The Afrcan giant rat heart muscle have a length ranging from of $72.5 \mu \mathrm{m}$ to $115 \mu \mathrm{m}$ and width ranging from $47.5 \mu \mathrm{m}$ to $62.5 \mu \mathrm{m}$, with intercellular space which ranges from $25 \mu \mathrm{m}$ to $32.5 \mu \mathrm{m}$. The results of the histomorphometric measurements of cardiac muscle fibres are shown in Table5. 


\section{Histological Observation of the Rodent's Heart}

The result of the histological observation of the hearts of the three Rodent species stained with the H\&E and Rafferty's special staining proce-dures show both crossstriational arrangement of the heart muscles with the intercalated disks and cardiac muscle cells. Figure (1) shows the heart muscle of the Wistar rats showing the cardiac muscles with striated muscle fibres and nuclei while Figure (2) shows the heart muscle of the Wistar rats with cardiac striated muscle fibres and nuclei of muscle cells stained with Rafferty Special stain. Figure (3) shows the heart muscle of the African giant rats showing cardiac muscle with striated muscle fibres and nuclei stained using heamatoxylin and eosine stain while Figure (4) shows the heart muscle of the African giant rats showing the cardiac muscle with striated muscle fibres and nuclei using rafferty special staining procedure. Figure (5) shows the heart muscle of the rabbit showing the cardiac muscle with striated muscle fibres and muscle nuclei using heamatoxylin and eosine stain while Figure (6) shows the heart muscle of the rabbit showing the cardiac muscle with striated muscle fibres and muscle nuclei using rafferty staining procedure.

\section{Discussion}

Morphologically the shape and orien-tation of the heart of the three mammalian species look alike but the most significant difference lies in the size of the hearts which was justi-fiable owing to the body sizes and the body weights of the three animals differed as a whole (Romer et al., 1977; Cecie et al., 2009). Compa-ratively, it was observed that there were significant differences regarding the heartbeats of the three animals pecies. It was observed that the smaller the mammal, the faster the heartbeat per minute which showed that the heart of the Wistar rats beat was faster than the African giant rats and then followed by that of the Rabbits which is in agreement with the observation made by Kriegs et al. (2006). From the result, it can be observed that the African giant rats have the largest and the thickest heart amongst the three mammals while the Wistar rats heart was the smallest. Morphometrically, it was be observed from the study that the African giant rat has the largest heart amongst the three mammalian species which was evident from the mean value obtained which showed a significant difference between the animls. As for the thickness of the walls of the heart chambers and valves showed significant differences between the species of the 
bigger the animal, the bigger the heart and the thicker the heart walls of the animals (Donalson, 1999; Utsumi et al., 2004; Müller et al., 2010; Davoust et al., 2013).

Histologically, the heart of the three rodent species are similar in the nature and arrangement of the cardic muscle fibers of which various sections through the hearts showed cardiac muscles fibres as well as intercalated disks which are similar to that of humans (Kermack and Kermack, 1984; Eroschenko, 2005; Witmer et al., 2010). The shape and structure of the heart muscle cells are similar but the size differed due to the differences in the sizes of their body and their body weight. This is true since the size of the body determines the size of the other organs and tissues of the body (Venzke, 1975; Ibegbu et al., 2014). The length of the muscle fibers can be used to determine the length of the heart and as such the longer the cardiac muscle fibers the longer the heart of the specie (Utsumi et al., 2004).

\section{Conslusion}

Significant differences were observed in the morphometrics of the various hearts of the three rodent species. It could also be derived from the study that the differential rates of heartbeats of the mam- malian species could be associated to their body weight and their body sizes. The heart muscles of rodents showed great simi-larities to that of humans and other related animal species and as such could be very useful in the comparative anatomy of other mammalian species.

\section{References}

Ajayi, S.S (1975): Domestication of the African giant rat (Cricetomys gambia-nus).Kwara State Printing and Publishing Corporation. Ilorin, Nigeria. Pp. 132-133.

Baumans V, Remie R, Hackbarth HJ, Timmerman A (2001): Experimental procedures. In: Principies of Laboratory Animal Scienceln Van Zutphen LFM, Baumans V, Beynen AC, (eds). Amsterdam: Elsevier, $313-333$.

Betelak KF, Margiotti EA, Wohlford ME, Suzuki DA. (2001): The use of titanium implants and prosthodontic techniques in the preparation of non-human primates for long-term neuro-nal recording studies.J Neurosci Methods.112(1): 9-20.

Caldwell, R (2006): Comparative Anatomy: Andreas Vesalius: Comparative Anatomy: Andreas Vesalius. University of California 
Museum of Paleontology. Retrieved 20/05/2014.

Campbell, NA. and Reece, JB. (2002): Biology.San Francisco, CA: Benjamin Cummings. pp. 438-439.

Cecie S., Christine E.; Lisa S. (2009): Biology; today and tomorrow with physiology. Cengage Learning, New York. 3rd Ed.Pp123235.

Cooper, RG (2008): Care, Husbandry and Disease of the African giant rat. Journal of South AfricaVeterinary Association 79 (2): 62-66.

Davoust B, de Biasi C, Demoncheaux JP, Diatta G, Pasqualini C, Piarroux R. (2013): Liver capillariasis (Calodium hepati-cum) in rodents from Ituri (DRC) and Dakar (Senegal). Bull Soc Pathol Exot. Dec 22.

Donalson, HH. (1999): On the relationships of body length to body weight and to the weight of the brain and of the spinal cord in albino rats. Journ of Comparative Neurology. 19:55-157

Dyce, KM.; Sack, WO and Wensing, CJL.(1996): Text-book of Veterinary Ana-tomy, $2^{\text {nd }}$ edition (W.B. Saunders Company).
Eroschenko VP (2005): Di Fiore's atlas of histology with functional Correlations. Lippincott Williams \& Wilkins.

Happold, RF. (1987): Mammals of Nigeria. Clarendon Press, Oxford. Pp. 124-125.

Ibegbu, AO; Adubazi P; Yahaya, BO; Musa, SA. (2014):

Comparative Micromorphological Studies of the Cerebrum in Three Mammalian Species: Rabbits (Oryctolagus cuniculus), Wistar Rats (Rattus norvegicus) and African Giant Rats (Cricetomys gambianus). Jour. Vet Anatomy 7 (1):31-46.

Kriegs JO, Churakov G, Kiefmann M, Jordan U, Brosius J, Schmitz J. (2006): Retroposed elements as archives for the evolutionary history of placental mammals. PLoS Biol. 4(4): e91.

Kemp, TS. (1982): Mammal-like reptiles and the origin of mammals. London: Academic Press. p. 363.

Kermack, DM and Kermack, KA. (1984): The evolution of mammalian characters. Croom Helm.

Kingdon, J. (1997): The Kingdon Field Guide to African Mammals. p. 199-200. 
Müller K, Horn B, Fritsch G, Range F, Klopfleisch R. (2010): Chronic heart failure due to severe endo-cardiosis in a Gambian giant pouched rat (Cricetomys gambianus). J. Zoo Wildl Med. 41(1):137139.

Nowak R.M and Paradiso JL. \{1991): Walkers mammals of the world. John hopkins university press.

Perry, ND. (2006): New invasive species in southern Florida: Gambian rat (Cricetomys gambianus). Journal of Mammalogy, 87: 262-264.

Romer, AS; Parsons,MN; Thomas S. (1977): The vertebrate body. Philadelphia, PA: Holt-Saunders international. pp. 437-442.

Sellke, T; Bayarri, MJ.; Berger, JO. (2001): Calibration of $p$ Values for Testing Precise Null Hypotheses. The American Statistican 55 (1): 62-71.

Sharon L and Crowell D. (2010): Behavior of Exotic Pets. Wiley Blackwell, p.70

Utsumi, M.; Moriguchi, K.; Takahashi, H.; Kinoshita, C.; Togari, A.; Mizutani, M.; Ohno, N. (2004): Age-related changes of the ultrastructure in the cardiomyopathic

J. Vet. Anat. hamster (UM-X7.1 Syrian hamster) parathyroid gland. Histology and Histopathology Journal; 19(3): 815821.

van der Straeten, E., Kerbis $\mathbf{P}$ J., Howell, K.; Oguge, N. (2008): Cricetomys gambianus. The IUCN Red List of Threatened Species. www.iucnredlist.org. Accessed on 01 July 2014.

Van Zuphten LFM, Baumans V, Beynen AC. (2001): Principles of laboratory animal science. Amsterdam. Pp.313-333.

Venzke WG. (1975): The Anatomy of Domestic Animals, volume 1and $25^{\text {th }}$ Edition Saunders, Philadelphia. Endo-crinology In Getty R. (Ed) Sisson and Grossman.Pp.32120.

Weiss AT, Delcour NM, Meyer A, Klopfleisch R. (2010): Efficient and Cost-Effective Extraction of Genomic DNA From Formalin-Fixed and Paraffin-Embedded Tissues. Veteri-nary Pathology 227 (4): 834838.

Wilson DE and Burnie D. ed. (2001): Animal: The Definitive Visual Guide to the World's Wildlife $1^{\text {st }}$ ed. DK Publishing. pp. 86-89.

Wilson, DE.; Reeder, DM. eds. (2005): Mammal Species of the 
World (3rd ed.).Johns Hopkins

University Press. p.xxvi.

Witmer GW, Snow NP, Burke PW. (2010): Potential attractants for detecting and removing invading Gambian giant pouched rats (Cricetomys gambianus). Pest Manag Sci. 66(4):412-416.

Young, JZ. (1981): The life of vertebrates. $3^{\text {rd }}$ Ed. Oxford University Press, Pp 358-363.

Corresponding Author Address:

Dr A. O. Ibegbu: Department of Human Anatomy, Faculty of Medicine, Ahmadu Bello University Zaria-Kaduna StateNigeria 81006.

E-mail:

aoibegbu@abu.edu.ng;aoibegbu@yaho o.com;

Phone:+2348032188042 
Histomorph. of the heart in three mammalian species

lbegbu et al.

Table (1): Descriptive statistical analysis of the lenght of the heart chambers in the three species.

\begin{tabular}{|c|c|c|c|c|}
\hline Animals & $\begin{array}{c}\text { RV(Mean } \pm \text { SEM) } \\
\quad(n=5)\end{array}$ & $\begin{array}{l}\text { LV(Mean } \pm \text { SEM) } \\
\quad(n=5)\end{array}$ & $\begin{array}{l}\text { LA(Mean } \pm \text { SEM) } \\
\qquad(n=5)\end{array}$ & $\begin{array}{l}\text { RA(Mean } \pm \text { SEM) } \\
(n=5)\end{array}$ \\
\hline AGR & $1.93 \pm 0.03 * * *$ & $1.63 \pm 0.03 *$ & $1.27 \pm 0.15^{* * *}$ & $0.93 \pm 0.067$ **** \\
\hline Rabbit & $1.37 \pm 0.29 * * * *$ & $1.10 \pm 0.07^{*}$ & $0.90 \pm 0.06 * *$ & $1.13 \pm 0.03 * * *$ \\
\hline Wistar R & $0.93 \pm 0.03 * * *$ & $0.70 \pm 0.06 *$ & $0.43 \pm 0.03 * *$ & $0.27 \pm 0.03^{* * * *}$ \\
\hline
\end{tabular}

${ }^{*}=\mathrm{P}<0.05 \quad * *=\mathrm{P}<0.01 \quad * * *=\mathrm{P}<0.001 ; \mathrm{RV}=$ right ventricle; $\mathrm{LV}=$ left ventricle;

$\mathrm{RA}=$ right atrium; $\mathrm{LA}=$ left atrium.

Table (2): Descriptive statistical analysis of the width of the heart chambers of the three species.

\begin{tabular}{|c|c|c|c|c|}
\hline Animals & RV(Mean \pm SEM) & LV(Mean \pm SEM) & LA(Mean \pm SEM) & RA(Mean \pm SEM) \\
\hline & $(n=5)$ & $(n=5)$ & $(n=5)$ & $(n=5)$ \\
\hline AGR & $0.33 \pm 0.09 *$ & $0.33 \pm 0.33 * * *$ & $0.38 \pm 0.02 * * *$ & $0.27 \pm 0.03 * *$ \\
\hline Rabbit & $0.12 \pm 0.06 *$ & $0.30 \pm 0.00 * * *$ & $0.22 \pm 0.06 * * *$ & $0.20 \pm 0.00 * *$ \\
\hline $\begin{array}{l}\text { Wistar } \\
\text { rat }\end{array}$ & $0.10 \pm 0.33^{*}$ & $0.08 \pm 0.03^{* * * *}$ & $0.07 \pm 0.03 * * *$ & $0.1033 \pm 0.03 * *$ \\
\hline $\begin{array}{l}*=P \\
R A=\end{array}$ & LA & $\mathrm{m}$. & & ; LV = le \\
\hline
\end{tabular}

Table (3): Descriptive statistical analysis of the thickness of the heart chambers and valves in the three species.

\begin{tabular}{|c|c|c|c|c|c|c|c|}
\hline Animals & $\begin{array}{c}\mathrm{RV}(\mathrm{Mean} \pm \text { SEM }) \\
(\mathrm{n}=5)\end{array}$ & $\begin{array}{c}\text { LV(Mean } \pm \text { SEM }) \\
(\mathrm{n}=5)\end{array}$ & $\begin{array}{c}\text { LA(Mean } \pm \text { SEM }) \\
(n=5)\end{array}$ & $\begin{array}{c}\text { RA(Mean } \pm \text { SEM }) \\
(\mathrm{n}=\mathbf{5})\end{array}$ & $\begin{array}{c}\text { IVS(Mean } \pm \text { SEM) } \\
(\mathrm{n}=5)\end{array}$ & $\begin{array}{c}\text { LAV }(\text { Mean } \pm \text { SEM }) \\
(n=5)\end{array}$ & $\begin{array}{c}\text { RAV(Mean } \pm \text { SEM }) \\
(\mathrm{n}=5)\end{array}$ \\
\hline AGR & $0.20 \pm 0.07$ & $0.46 \pm 0.03$ & $0.50 \pm 0.03^{* * * * *}$ & $0.18 \pm 0.02^{* * * *}$ & $0.50 \pm 0.2$ & $0.27 \pm 0.03^{* * * *}$ & $0.37 \pm 0.02 * * *$ \\
\hline Rabbit & $0.53 \pm 0.03$ * * & $0.33 \pm 0.03$ * & $0.20 \pm 0.0$ *** & $0.63 \pm 0.03$ *** & $0.52 \pm 0.2$ & $0.09 \pm 0.03$ & $0.32 \pm 0.02$ \\
\hline Wistar rat & $0.17 \pm 0.03$ * * & $0.47 \pm 0.03$ * & $0.46 \pm 0.03$ *** & $0.14 \pm 0.01$ *** & $0.43 \pm 0.04$ & $0.01 \pm 0 . * * *$ & $0.01 \pm 0.3$ *** \\
\hline
\end{tabular}

J. Vet. Anat. 
Histomorph. of the heart in three mammalian species

Ibegbu et al.

Table (4): Correlation between the total body weight and the heart weight and heart volume.

\begin{tabular}{|c|c|c|c|}
\hline RABBIT & PARAMETERS & HWT & HV \\
\hline 5 & TBWT & $0.737^{*}$ & $0.918^{*}$ \\
\hline 5 & HWT & ---------- & $0.945^{*}$ \\
\hline 5 & $\mathrm{HV}$ & ----------- & --------- \\
\hline \multicolumn{4}{|l|}{ AGR } \\
\hline 5 & TBWT & 0.371 & $0.866^{*}$ \\
\hline 5 & HWT & --------- & $0.786^{*}$ \\
\hline 5 & $\mathrm{HV}$ & --------- & -------- \\
\hline \multicolumn{4}{|l|}{ WISTAR RAT } \\
\hline 5 & TBWT & $1.000^{*}$ & ---------- \\
\hline 5 & HWT & --------- & --------- \\
\hline 5 & $\mathrm{HV}$ & --------- & --------- \\
\hline
\end{tabular}

TBWT- Total body weight; HWT- heart weight; HV- heart volume. ${ }^{*} \mathrm{P}<0.001$

Table (5): lenght and width of cardiac muscle and intercellular space between two adjacent muscle fibres.

\begin{tabular}{|c|c|c|c|c|c|c|}
\hline \multirow[t]{2}{*}{ Anims } & \multicolumn{2}{|c|}{ LOCM $(\mu \mathrm{m})$} & \multicolumn{2}{|c|}{ WOCM ( $\mu \mathrm{m})$} & \multicolumn{2}{|c|}{ ICBN $(\mu \mathrm{m})$} \\
\hline & $\begin{array}{c}\text { Mean } \pm S D \\
N=5\end{array}$ & Range & $\begin{array}{c}\text { Mean } \pm S D \\
N=5\end{array}$ & Range & $\begin{array}{c}\text { Mean } \pm S D \\
N=5\end{array}$ & Range \\
\hline Rabb & $74.51 \pm 12.11^{*}$ & $57.5-100$ & $38.22 \pm 7.2^{*}$ & $32.5-50$ & $23.12 \pm 5.1^{*}$ & $17.5-25$ \\
\hline AGR & $87.21 \pm 10.21^{*}$ & $72.5-115$ & $51.15 \pm 8.1^{*}$ & $47.5-62.5$ & $31.53 \pm 8.1^{*}$ & $25-32.5$ \\
\hline Wistar & $52.12 \pm 11.25$ & $37.5-72.5$ & $32.42 \pm 5.2$ & $30-42.5$ & $21.45 \pm 4.3$ & $20-25$ \\
\hline
\end{tabular}

LOCM = length of cardiac muscle; WOCM = width of cardiac muscle; ICBN = intercellular space between the cardiac muscle fibers. * $P \leq 0.05$ 


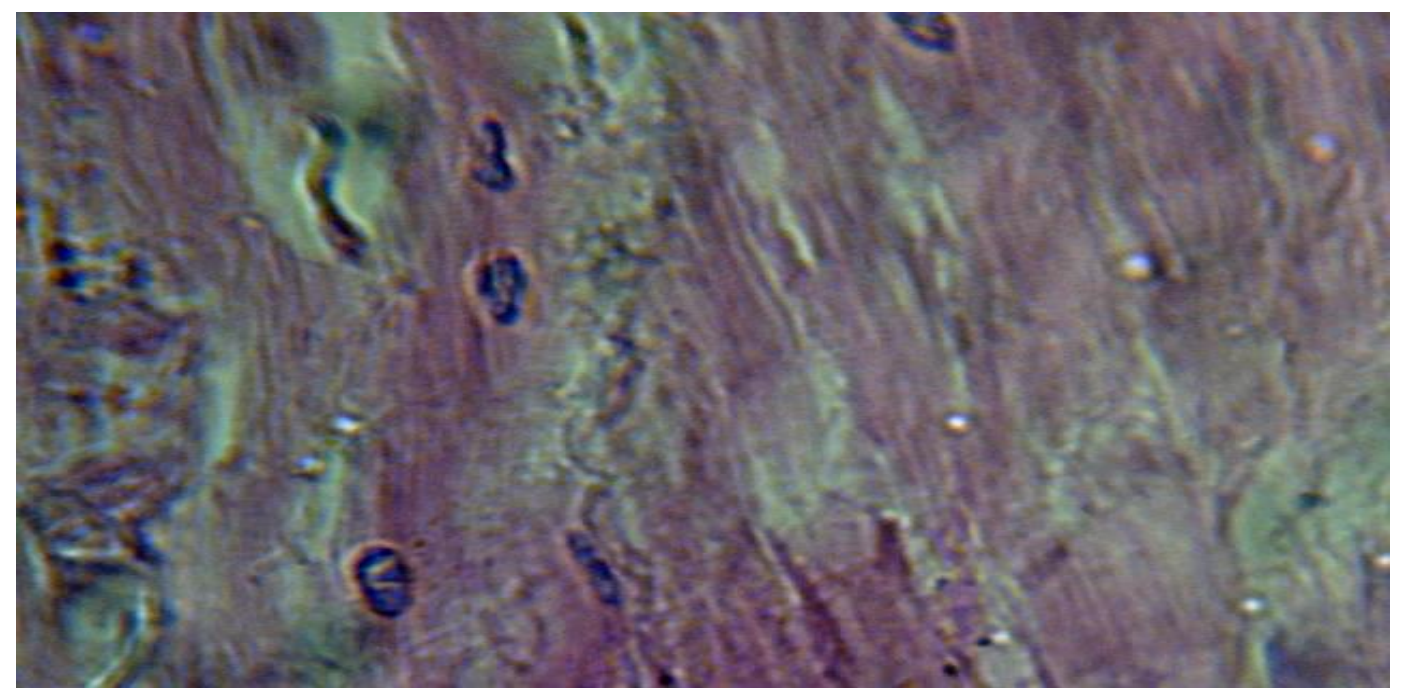

Fig (1): Showing the arrangements of the cross-striations of the cardiac muscle of the heart of adult Wistar rats, $\mathrm{NC}=$ nuclei of muscle cells, $\mathrm{IC}=$ intercalated disks $\mathrm{H}$ \& $\mathrm{E}$ stain (mag. X400)

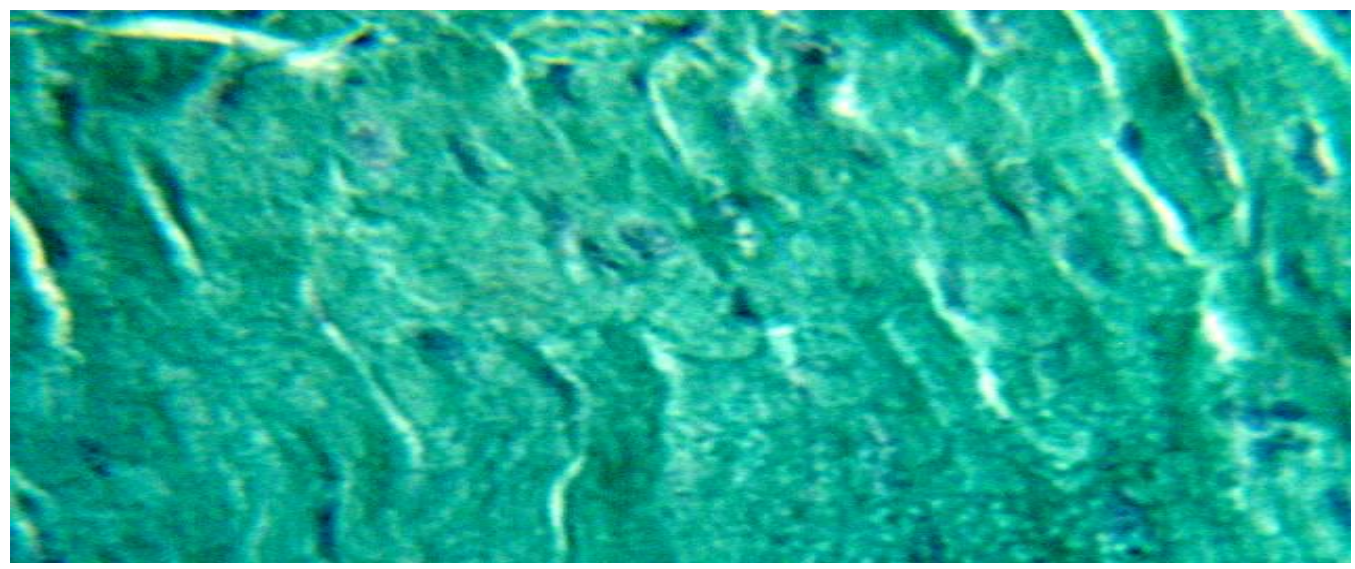

Fig (2): Arrangements in the cross-striations of cardiac muscle of the heart of Wistar rats, $\mathrm{NC}=$ nuclei of muscle cells, $\mathrm{IC}=$ intercalated disks. Rafferty special stain (mag. $\mathrm{X} 400)$ 


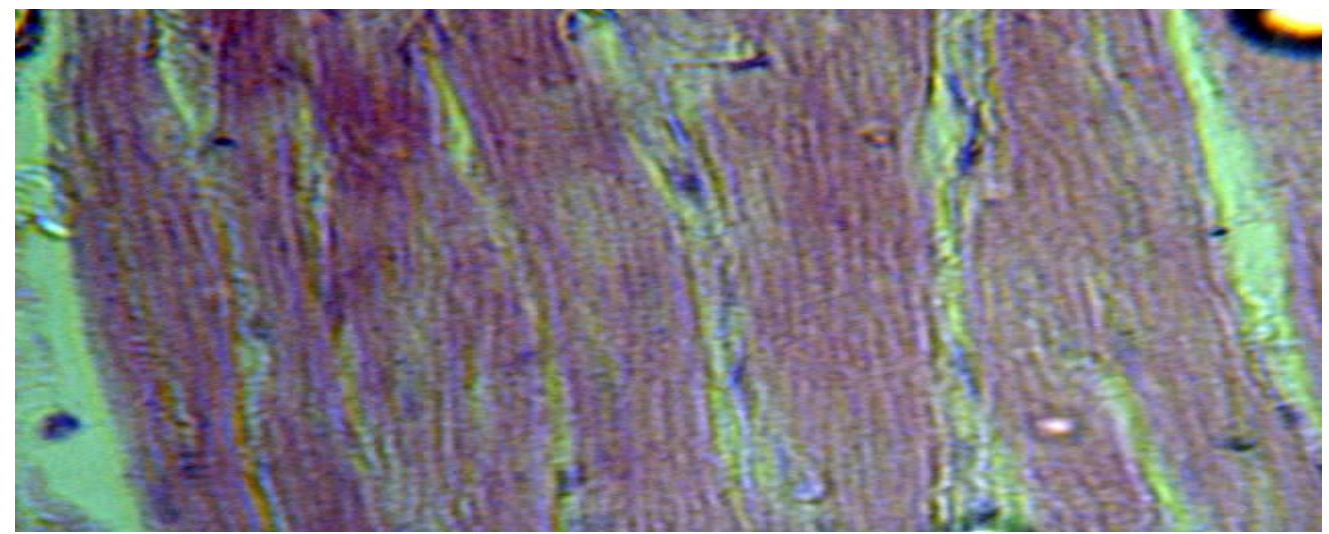

Fig (3): Showing the arrangements in the cross-striations of cardiac muscle of the heart of African giant rats, $\mathrm{NC}=$ nuclei of the larger muscle cells, $\mathrm{IC}=$ intercalated disks. $\mathrm{H} \& \mathrm{E}$ stain (mag. X400).

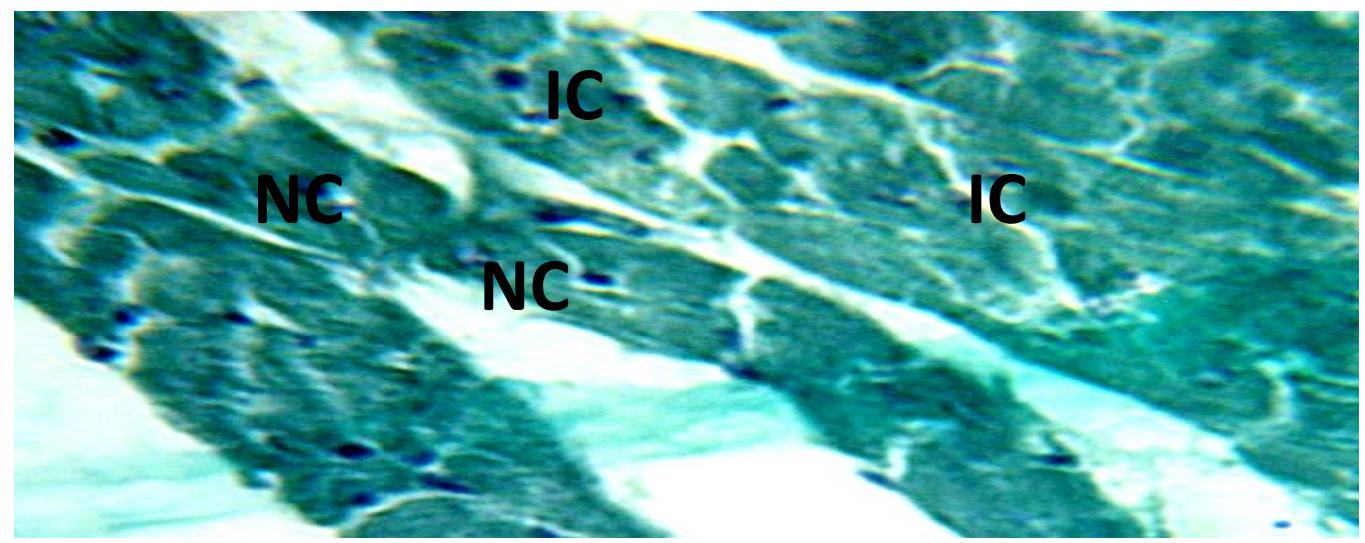

Fig (4): Showing the arrangements of the cross-striations of cardiac muscle of the heart of African giant rats. NC= nuclei of larger muscle cells, $I C=$ intercalated disks. Rafferty special stain (mag. X400). 


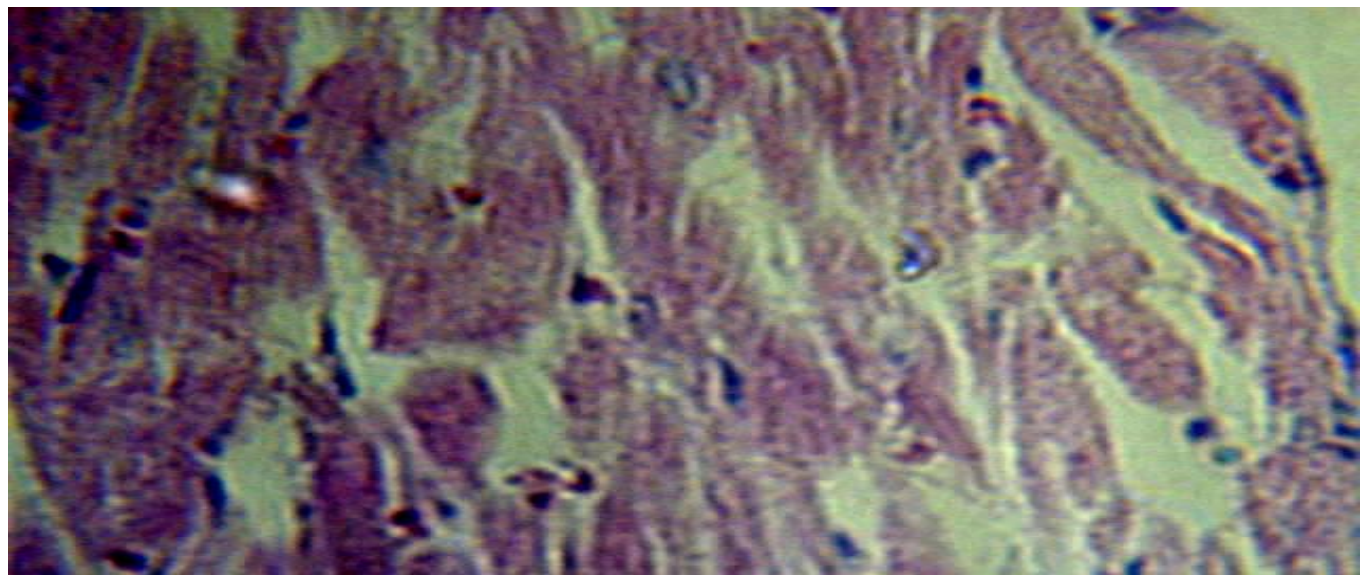

Fig (5): Showing the arrangement of the cross-striations of cardiac muscle of the heart of Rabbits. $\mathrm{NC}=$ nuclei of larger muscle cells, $\mathrm{IC}=$ intercalated disks. $\mathrm{H} \& \mathrm{E}$ stain (mag. X400)

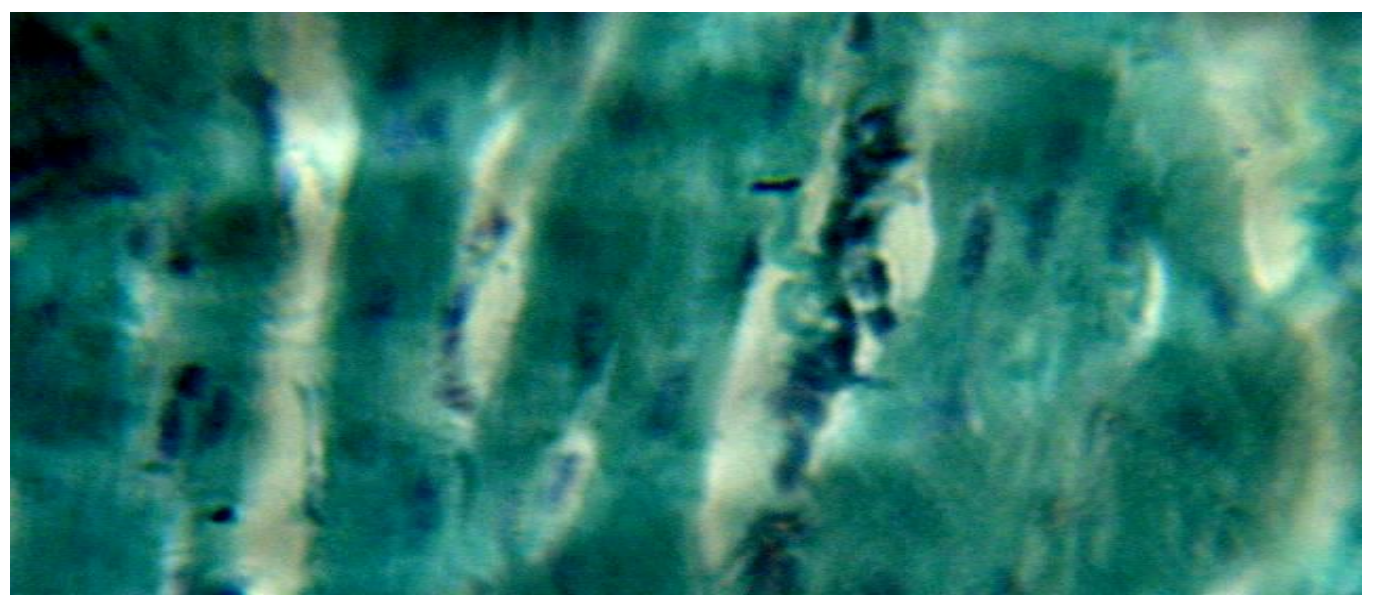

Fig (6): Showing the arrangement of the cross-striations of cardiac muscle of the heart of Rabbits. $\mathrm{NC}=$ nuclei of larger muscle cells, $\mathrm{IC}=$ intercalated disks .Rafferty special stain (mag. X400) 